\title{
Analysis of $N$-Nitrosamine Migration from Rubber Teats and Soothers
}

\author{
Motoh Mutsuga*, Miku Yamaguchi, Yoko Kawamura \\ Division of Food Additives, National Institute of Health Sciences, Tokyo, Japan \\ Email: *mutsuga@nihs.go.jp
}

Received April 12, 2013; revised May 13, 2013; accepted June 1, 2013

Copyright (C) 2013 Motoh Mutsuga et al. This is an open access article distributed under the Creative Commons Attribution License, which permits unrestricted use, distribution, and reproduction in any medium, provided the original work is properly cited.

\begin{abstract}
A testing method for $N$-nitrosamines and $N$-nitrosatable substances in rubber teats and soothers was modified. $N$-Nitrosamines are generally analyzed using either a nitrogen chemiluminescence detector (NCD) or a thermal energy analyzer (TEA). However, because few testing laboratories are equipped with these devices, it is difficult to conduct these tests. Therefore, an analysis method for $N$-nitrosamines using the more widespread gas chromatography-mass spectrometry (GC-MS) method was improved. In addition, EN 12868 was used to prepare the test solutions because of its worldwide use and compliance with EU regulations. Using GC-MS, EN 12868 method targeting ten kinds of $N$-nitrosamines was modified. The determination limits of the method were $1.0-1.5 \mu \mathrm{g} / \mathrm{kg}$ for $N$-nitrosamines and $4-6$ $\mu \mathrm{g} / \mathrm{kg}$ for $N$-nitrosatable substances. Quantification was possible at $1 / 5$ or less and $1 / 15$ or less, respectively, of the regulation values listed in EU Directive 93/11/EEC. In terms of application, there were no problems with the selectivity of the detector. The recoveries were $58 \%-109 \%$ for $N$-nitrosamines and $59 \%-102 \%$ for $N$-nitrosatable substances. Screening and verification were possible by measuring the amount of secondary amines in the boiled solution and migration solution.
\end{abstract}

Keywords: $N$-Nitrosamine; $N$-Nitrosatable Substances; Secondary Amine; Rubber Teat and Soother; GC-MS

\section{Introduction}

$N$-nitrosamines are chemical compounds with $N$-nitroso groups ( $>\mathrm{N}-\mathrm{N}=\mathrm{O}$ ), some of which are considered problematic because they are carcinogenic. The International Agency for Research on Cancer (IARC) classifies $\mathrm{N}$-nitrosodimethylamine (NDMA) and $\mathrm{N}$-nitrosodiethylamine (NDEA) in Group 2A (probably carcinogenic to humans) and $N$-nitrosodipropylamine (NDPA), $N$-nitrosodibutylamine (NDBA), $N$-nitrosopiperidine (NPIP), $N$-nitrosopyrrolidine (NPYR), and $N$-nitrosomorpholine (NMOR) in Group 2B (possibly carcinogenic to humans) [1]. Furthermore, $N$-nitrosodibenzylamine (NDBzA), $N$-nitroso $\mathrm{N}$-methyl $\mathrm{N}$-phenylamine (NMPhA), and $\mathrm{N}$-nitroso $\mathrm{N}$ ethyl $N$-phenylamine (NEPhA) have been reported to be mutagenic [2-5].

Dithiocarbamic acids and thiurams are added to rubber products as vulcanization accelerators in the production process and decompose to form secondary amines. In addition, diphenylamine-type secondary amines are some times added as antioxidants. When some of them react

\footnotetext{
"Corresponding author.
}

with nitrogen oxides such as nitrous acid, which occurs in the environment or during the manufacturing process, $\mathrm{N}$-nitrosamines are formed. Secondary amines migrating from rubber products may also react with nitrous acid in the stomach to form $N$-nitrosamines.

For rubber teats and soothers, EU Directive 93/11/ EEC limits the total migration of $N$-nitrosamines to 10 $\mu \mathrm{g} / \mathrm{kg}$ or less and the total migration of $N$-nitrosatable substances to $100 \mu \mathrm{g} / \mathrm{kg}$ or less [6]. Furthermore, the American Society for Testing and Materials (ASTM) F1313-90, the prevalent standard in the US, limits the inclusion of $N$-nitrosamines to $10 \mu \mathrm{g} / \mathrm{kg}$ or less per chemical compound, with the total amount not exceeding 20 $\mu \mathrm{g} / \mathrm{kg}$ [7]. In contrast, the Food Sanitation Law in Japan sets no distinct standards for $N$-nitrosamines and $N$-nitrosatable substances.

EN 12868, which is based on the EU Directive, and ASTM F1313-90 are the most generally used testing methods for $N$-nitrosamines in rubber teats and soothers. EN 12868 is a test that targets 11 kinds of $N$-nitrosamines and uses artificial saliva for migration. The amount of $\mathrm{N}$ nitrosamines and $N$-nitrosatable substances in the migrated solution are then measured [8]. On the other hand, 
ASTM F1313-90 is a material test in which the sample is homogenized by adding liquid nitrogen and then subjected to Soxhlet extraction with dichloromethane. The amount of $N$-nitrosamines in the material is then measured.

Many researchers have analyzed the $\mathrm{N}$-nitrosamine content of teats and soothers [9-19], and all of these analyses have been conducted using one of the two methods mentioned above, or a modified version of them. With these methods, either a nitrogen chemiluminescence detector (NCD) or a thermal energy analyzer (TEA), which has very good sensitivity and selectivity in terms of detecting $N$-nitrosamines, is necessary. However, in Japan these devices are not widespread, and few testing laboratories have them.

In recent years, the headspace solid phase microextraction gas chromatography-MS (HS-SPME-GC-MS), GCnitrogen phosphorus detector (GC-NPD) and liquid chromatography-tandem mass spectrometry (LC-MS/MS) technique have been reported [20-24]. Following this, we have attempted to use the widespread GC-MS method to analyze $N$-nitrosamines in rubber teats and soothers. EN 12868 was chosen as the test solution preparation method because it is in line with EU regulations and is widely used around the world. A testing method was improved for $N$-nitrosamines and $N$-nitrosatable substances in rubber teats and soothers. Furthermore, a screening and verification method using liquid chromatography (LC)-MS (LC-MS) was developed.

\section{Testing Method}

\subsection{Samples}

A $2.3 \mathrm{~mm}$ thick isoprene rubber sheet was used. Its composition is followed. zinc oxide $0.5 \mathrm{phr}$ (per hundred rubber), stearic acid $0.5 \mathrm{phr}$, sulfur $1 \mathrm{phr}$, zinc dimethyldithiocarbamate, zinc diethyldithiocarbamate, zinc dibutyldithiocarbamate, zinc $\mathrm{N}$-pentamethylene dithiocarbamate, zinc dibenzyldithiocarbamate, zinc ethylphenyl dithiocarbamate, and $\mathrm{N}$-oxydiethylene-2-benzothiazolesulfenamide $0.2 \mathrm{phr}$ each for polyisoprene rubber.

Samples of teats made from silicone rubber, isoprene rubber, and natural rubber purchased from retail stores in Tokyo were used.

\subsection{Reagents}

\section{1) $\mathrm{N}$-Nitrosamines}

$\mathrm{N}$-Nitrosodimethylamine (NDMA, $\geq 98 \%$ purity), $\mathrm{N}$ nitrosodiethylamine (NDEA, $\geq 98 \%$ purity), $N$-nitrosodipropylamine (NDPA, $\geq 98 \%$ purity), $N$-nitrosodibutylamine (NDBA, $\geq 95 \%$ purity), $N$-nitrosomorpholine (NMOR, $\geq 98 \%$ purity), and $N$-nitroso- $N$-methylaniline (NMPhA, $\geq 98 \%$ purity) were purchased from Tokyo Che- mical Industry Co., Ltd., N-nitrosodibenzylamine (NDBzA, $\geq 99 \%$ purity) was purchased from Wako Pure Chemical Industries Ltd., $N$-nitrosopiperidine (NPIP, $\geq 95 \%$ purity) was purchased from Sigma International Ltd., $N$-nitrosopyrrolidine (NPYR, $\geq 98 \%$ purity) was purchased from Aldrich Chemical Co., $\mathrm{N}$-nitroso $\mathrm{N}$-ethyl $\mathrm{N}$-phenylamine (NEPhA, $\geq 98 \%$ purity) was purchased from Toronto Research Chemicals Inc., and $N$-nitrosodiisopropylamine (NDiPA, $\geq 95 \%$ purity) was purchased from LGC Standards.

\section{2) Secondary Amines}

Dimethylamine hydrochloride (DMA, $\geq 99 \%$ purity), diethylamine (DEA, $\geq 99 \%$ purity), dipropylamine (DPA, $\geq 99 \%$ purity), dibutylamine (DBA, $\geq 99 \%$ purity), piperidine (PIP, $\geq 99 \%$ purity), pyrrolidine (PYR, $\geq 98 \%$ purity), morpholine (MOR, $\geq 99 \%$ purity), dibenzylamine (DBzA, $\geq 97 \%$ purity), $N$-methylaniline (MPhA, $\geq 98 \%$ purity), and $N$-ethylaniline (EPhA, $\geq 99 \%$ purity) were purchased from Tokyo Chemical Industry Co., Ltd.

\section{3) $\mathrm{N}$-Nitrosamine Standard Solution}

The internal standard stock solution consisted of 10 $\mathrm{mg}$ of NDiPA dissolved in hexane to $100 \mathrm{~mL}(100 \mu \mathrm{g} /$ $\mathrm{mL}$ ). The internal standard solution was made by diluting the internal standard stock solution to $0.2 \mu \mathrm{g} / \mathrm{mL}$ with acetone.

The $N$-nitrosamine standard stock solutions were prepared by dissolving $20 \mathrm{mg}$ each of the $N$-nitrosamines separately in acetone to make $20 \mathrm{~mL}$ each. Next, $5 \mathrm{~mL}$ of each solution was diluted to $100 \mathrm{~mL}$ with hexane $(50 \mu \mathrm{g} /$ $\mathrm{mL}$ ). The $N$-nitrosamine standard solutions consisted of internal standard stock solution added to the $N$-nitrosamine standard stock solution, appropriately diluted with hexane so that the $N$-nitrosamines concentration was 0.01 $10 \mu \mathrm{g} / \mathrm{mL}$ and that of the internal standard was $0.2 \mu \mathrm{g} /$ $\mathrm{mL}$.

\section{4) Secondary Amine Standard Solution}

The secondary amine standard stock solutions were prepared as followed. Each $50 \mathrm{mg}$ of secondary amines (except for DMA, of which $90.6 \mathrm{mg}$ was used because it is a hydrochloride) was dissolved separately in methanol to $50 \mathrm{~mL}$. Next, $1 \mathrm{~mL}$ of each solution was diluted to 20 $\mathrm{mL}$ with water $(50 \mu \mathrm{g} / \mathrm{mL})$, and then further diluted to $0.05-5 \mu \mathrm{g} / \mathrm{mL}$ with artificial saliva.

The secondary amine standard solutions were prepared by adding $0.1 \%$ trifluoroacetic acid (TFA) to $2 \mathrm{~mL}$ of the secondary amine standard stock solution at each concentration level to make $10 \mathrm{~mL}(0.01-1 \mu \mathrm{g} / \mathrm{mL})$.

\section{5) Artificial Saliva}

Artificial saliva was prepared by dissolving $4.2 \mathrm{~g}$ sodium bicarbonate, $0.5 \mathrm{~g}$ sodium chloride, $0.2 \mathrm{~g}$ potassium carbonate, and $0.03 \mathrm{~g}$ sodium nitrite in $950 \mathrm{~mL}$ of water, then adjusted to $\mathrm{pH} 9$ with $0.1 \mathrm{~mol} / \mathrm{L} \mathrm{NaOH}$, and diluted to a total volume of $1000 \mathrm{~mL}$ with water. 


\subsection{GC-MS Analysis}

The GC-MS analysis was performed with an Agilent $6890 \mathrm{~N}$ gas chromatograph and 5973 inert mass spectrometer (Agilent Technologies). GC conditions were as follows: column: DB-FFAP $(0.25 \mathrm{~mm}$ internal diameter, $15 \mathrm{~m}$ length, $0.25 \mu \mathrm{m}$ film thickness; Agilent Technologies); column temperature: $50^{\circ} \mathrm{C}-10^{\circ} \mathrm{C} / \mathrm{min}-160^{\circ} \mathrm{C}$ $20^{\circ} \mathrm{C} / \mathrm{min}-250^{\circ} \mathrm{C}(2 \mathrm{~min})$; injection volume: $1 \mu \mathrm{L}$; injection port temperature: $120^{\circ} \mathrm{C}$; transfer line temperature: $250^{\circ} \mathrm{C}$; ion source temperature: $230^{\circ} \mathrm{C}$; carrier gas: He at a flow rate of $1.0 \mathrm{~mL} / \mathrm{min}$; split ratio: $1: 1$; ionization voltage: $70 \mathrm{eV}$ (electron impact mode); measurement mode: selected ion monitoring (SIM).

\subsection{LC-MS Conditions}

The LC-MS analysis was performed with an Acquity Series LC-MS, Waters Corporation. The LC-MS conditions were as follows: column: Acquity BEH C18 (100 $\mathrm{mm} \times 2.1 \mathrm{~mm}, 1.7 \mu \mathrm{m}$ particle diameter); column temperature: $40^{\circ} \mathrm{C}$; mobile phase: A, $0.1 \%$ TFA; $\mathrm{B} 0.1 \%$ TFA/ methanol, A:B (99:1) (1 min) $\rightarrow$ linear gradient $(6 \mathrm{~min})$ $\rightarrow \mathrm{A}: \mathrm{B}(1: 99)$ (3 $\mathrm{min})$; flow rate: $0.3 \mathrm{~mL} / \mathrm{min}$; injection volume: $10 \mu \mathrm{L}$; method of ionization: electrospray ionization (+); capillary voltage: $3 \mathrm{kV}$; ion source temperature: $150^{\circ} \mathrm{C}$; cone gas and flow rate: $\mathrm{N}_{2} 50 \mathrm{~L} / \mathrm{h}$; measurement mode: single ion recording (SIR).

\subsection{Preparation of Test Solutions}

For the boiled solution, each sample (10 g) was accurately weighed and immersed in a minimal amount of water and boiled for $10 \mathrm{~min}$. After removing the sample, water was added to make $100 \mathrm{~mL}$.

For the migration solution, the sample was cut vertically into two pieces and left to dry naturally overnight. Next, $80 \mathrm{~mL}$ of artificial saliva was added and the sample was left for $24 \mathrm{~h}$ at $40^{\circ} \mathrm{C}$ in the dark. This solution was transferred into a $100 \mathrm{~mL}$ measuring cylinder, and the sample was washed with $10 \mathrm{~mL}$ of artificial saliva and added to the washings in the measuring cylinder, which was finally made up to $100 \mathrm{~mL}$ with artificial saliva.

Using the boiled solution and migration solution, the following test solutions were prepared. $\mathrm{N}$-Nitrosamine test solution was prepared as follows. $75 \mathrm{~mL}$ of either boiled solution or migration solution was transferred into a separating funnel, $1 \mathrm{~mL}$ of the internal standard solution, $2 \mathrm{~mL}$ of $1 \mathrm{~mol} / \mathrm{L} \mathrm{NaOH}$ and $20 \mathrm{~mL}$ dichloromethane were added, and the funnel was shaken vigorously. The dichloromethane layer was separated from the upper layer, which was subsequently extracted using $20 \mathrm{~mL}$ of dichloromethane. The combined dichloromethane layers were dried using sodium sulfate, and $2 \mathrm{~mL}$ of hexane was added. The solution was concentrated at $\leq 35^{\circ} \mathrm{C}$ to slightly less than $1 \mathrm{~mL}$. Hexane was added to fix the volume at
$1 \mathrm{~mL}$.

The $N$-nitrosatable substance test solution was prepared as follows. $2 \mathrm{~mL}$ of $1 \mathrm{~mol} / \mathrm{L} \mathrm{HCl}$ was added to $20 \mathrm{~mL}$ of migration solution. The solution was shaken vigorously, then left in the dark for $30 \mathrm{~min}$. Next, the solution was transferred into a separating funnel and $1 \mathrm{~mL}$ of internal standard solution, $4 \mathrm{~mL}$ of $1 \mathrm{~mol} / \mathrm{L} \mathrm{NaOH}$ and $10 \mathrm{~mL}$ dichloromethane were added. After vigorous shaking, the dichloromethane layer was separated from the upper layer, which was subsequently extracted using $10 \mathrm{~mL}$ of dichloromethane. The combined dichloromethane layers were dried using sodium sulfate, and $2 \mathrm{~mL}$ of hexane was added. The solution was concentrated at $\leq 35^{\circ} \mathrm{C}$ to slightly less than $1 \mathrm{~mL}$. Hexane was added to fix the volume at 1 $\mathrm{mL}$.

The secondary amine test solution was prepared by diluting $1 \mathrm{~mL}$ of the boiled solution or migration solution to $5 \mathrm{~mL}$ with $0.1 \%$ TFA.

\subsection{Determination}

$\mathrm{N}$-Nitrosamines and $\mathrm{N}$-nitrosatable substances were determined using GC-MS with the internal standard method. The migration levels of each $N$-nitrosamine and $N$-nitrosatable substance per sample amount $(\mu \mathrm{g} / \mathrm{kg})$ were obtained.

The secondary amines in the boiled solution and migration solution were determined using LC-MS with the absolute calibration method. The migration levels of second-dary amine per amount of sample $(\mathrm{mg} / \mathrm{kg})$ were obtained.

\section{Study Results and Observations}

\subsection{Measurement Target Compounds}

A total of 11 kinds of $N$-nitrosamines are targeted for analysis in EN 12868: NDMA, NDEA, NDPA, NDBA, NPIP, NPYR, NMOR, NDBzA, NMPhA, NEPhA, and $N$-nitrosodiisononylamine (NDiNA). Of these, seven kinds are targeted for analysis in ASTM F1313-90: NDMA, NDEA, NDBA, NPIP, NPYR, NMOR, and NEPhA (Table 1). Of the 11 kinds listed in EN 12868, NDiNA and its precursor diisononylamine were not readily available commercially. In this study, ten kinds of $N$-nitrosamines were targeted for the analysis. Furthermore, a method was established for analyzing the ten kinds of secondary amines that are precursors to these $N$-nitrosamines (Table 2).

\subsection{GC-MS Analysis Conditions for $\mathrm{N}$-Nitrosamines}

$N$-Nitrosamine standard solutions were analyzed in the SCAN mode and determination ions were chosen from each mass spectrum (Table 1). The determinations were 
performed in the SIM mode using each determined ion.

When the injection port temperature was set to $250^{\circ} \mathrm{C}$, three peaks each were observed for NEPhA, NMPhA, and NDBzA (Figure 1). In these peaks, each precursor amine (EPhA, MPhA, and DBzA) was contained. These amines were assumed to be formed by decomposition at the injection port. The other peaks were thought to be the result of decomposition products or dimers of each amine, but they could not be identified. When the injection port temperature was set to $120^{\circ} \mathrm{C}$, the peaks became singular, their shapes were improved, and the peak intensity increased greatly (Figure 1). For the other $N$-nitrosamines, no difference was observed between $250^{\circ} \mathrm{C}$ and $120^{\circ} \mathrm{C}$, Therefore, the injection port temperature was set to $120^{\circ} \mathrm{C}$. The SIM chromatogram of the standard solution is shown in Figure 2. Under these conditions, the determi- nation limit is $0.005 \mu \mathrm{g} / \mathrm{mL}$ for each (Table 1).

\subsection{LC-MS Analysis Conditions for Secondary Amines}

The secondary amines that are the precursors to the $N$ nitrosamines were analyzed by LC-MS. An Acquity BEH C18 column, $0.1 \% \mathrm{TFA} /$ water and $0.1 \% \mathrm{TFA} / \mathrm{me}-$ thanol for the mobile phases were used. From the mass spectra of the secondary amines, $[\mathrm{M}+\mathrm{H}]^{+}$was detected as the base peak. Therefore, these were selected as the determined ions. The cone voltage was set at a value such that, for each amine, the peak area of the determined ion would become greatest. The cone voltage, determined ion, retention time, and determination limit are shown in Table 2. Mass chromatograms of the standard solutions are shown in Figure 3.

Table 1. $N$-nitrosamines targeted for testing by EN12868 and ASTM F1313-90.

\begin{tabular}{llccccccc}
\hline & \multicolumn{1}{c}{$N$-Nitrosamines } & CAS & EN12868 & $\begin{array}{c}\text { ASTM } \\
\text { F1313-90 }\end{array}$ & $\begin{array}{c}\text { Retention } \\
\text { time (min) }\end{array}$ & $\begin{array}{c}\text { Quantifying } \\
\text { ion }\end{array}$ & $\begin{array}{c}\text { Qualifying } \\
\text { ion }\end{array}$ & $\begin{array}{c}\text { Determination } \\
\text { limit }(\mathrm{ng} / \mathrm{mL})\end{array}$ \\
\hline NDMA & $N$-Nitrosodimethylamine & $62-75-9$ & + & + & 3.52 & 74 & 43 & 5 \\
NDEA & $N$-Nitrosodiethylamine & $55-18-5$ & + & + & 4.29 & 102 & 57 & 5 \\
NDiPA & $N$-Nitrosodiisopropylamine & $601-77-4$ & Is & - & 4.95 & 130 & 70 & 5 \\
NDPA & $N$-Nitrosodipropylamine & $621-64-7$ & + & Is & 5.84 & 70 & 130 & 5 \\
NDBA & $N$-Nitrosodibutylamine & $924-16-3$ & + & + & 7.89 & 84 & 158 & 5 \\
NPIP & $N$-Nitrosopiperidine & $100-75-4$ & + & + & 8.05 & 114 & 55 & 5 \\
NPYR & $N$-Nitrosopyrrolidine & $930-55-2$ & + & + & 8.46 & 100 & 68 & 5 \\
NMOR & $N$-Nitrosomorpholine & $59-89-2$ & + & + & 9.08 & 116 & 86 & 5 \\
NEPhA & $N$-Nitroso $N$-ethyl $N$-phenylamine & $612-64-6$ & + & + & 10.86 & 121 & 106 & 5 \\
NMPhA & $N$-Nitroso $N$-methyl $N$-phenylamine & $614-00-6$ & + & - & 10.94 & 107 & 106 & 5 \\
NDBzA & $N$-Nitrosodibenzylamine & $5336-53-8$ & + & - & 15.98 & 91 & 181 & 5 \\
NDiNA & $N$-Nitrosodiisononylamine & - & + & - & $*$ & $*$ & $*$ & $*$ \\
\hline
\end{tabular}

Is: used as internal standard; ${ }^{*}$ not quantified.

Table 2. Secondary amines (precursors to the $N$-nitrosamines targeted for measurement).

\begin{tabular}{|c|c|c|c|c|c|c|c|}
\hline \multirow{2}{*}{\multicolumn{2}{|c|}{ Secondary amines }} & \multirow{3}{*}{$\begin{array}{c}\text { CAS } \\
124-40-3\end{array}$} & \multirow{3}{*}{$\begin{array}{c}\begin{array}{c}\text { Retention time } \\
(\mathrm{min})\end{array} \\
1.01\end{array}$} & \multirow{3}{*}{$\begin{array}{c}\begin{array}{c}\text { Cone voltage } \\
\text { (V) }\end{array} \\
40\end{array}$} & \multirow{3}{*}{$\begin{array}{c}\begin{array}{c}\text { Quantifying } \\
\text { ion }\end{array} \\
46\end{array}$} & \multicolumn{2}{|c|}{ Determination limit } \\
\hline & & & & & & \multirow{2}{*}{$\begin{array}{c}\text { Standard solution } \\
(\mathrm{ng} / \mathrm{mL}) \\
2\end{array}$} & \multirow{2}{*}{$\begin{array}{c}\text { Per Sample } \\
(\mathrm{mg} / \mathrm{kg}) \\
0.1\end{array}$} \\
\hline DMA & Dimethylamine & & & & & & \\
\hline DEA & Diethylamine & $109-89-7$ & 1.65 & 30 & 74 & 2 & 0.1 \\
\hline DPA & Dipropylamine & $142-84-7$ & 3.37 & 30 & 102 & 2 & 0.1 \\
\hline DBA & Dibutylamine & $111-92-2$ & 4.57 & 30 & 130 & 2 & 0.1 \\
\hline PIP & Piperidine & $110-89-4$ & 2.67 & 35 & 86 & 2 & 0.1 \\
\hline PYR & Pyrrolidine & $123-75-1$ & 1.47 & 35 & 72 & 2 & 0.1 \\
\hline MOR & Morpholine & $110-91-8$ & 1.16 & 30 & 88 & 2 & 0.1 \\
\hline $\mathrm{EPhA}$ & Ethylaniline & $624-78-2$ & 3.93 & 30 & 122 & 4 & 0.2 \\
\hline MPhA & Methylaniline & $100-61-8$ & 3.52 & 30 & 108 & 4 & 0.2 \\
\hline DBzA & Dibenzylamine & $103-49-1$ & 5.20 & 30 & 198 & 2 & 0.1 \\
\hline
\end{tabular}



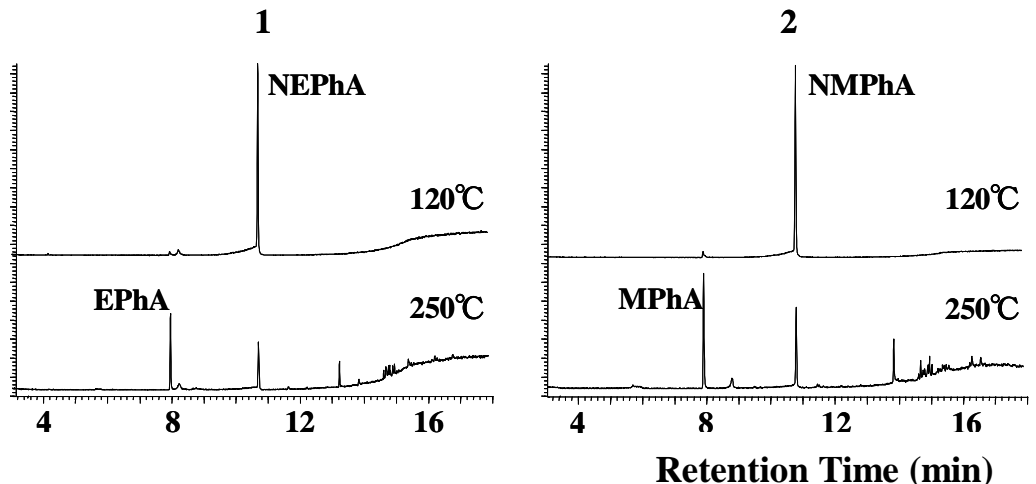

3

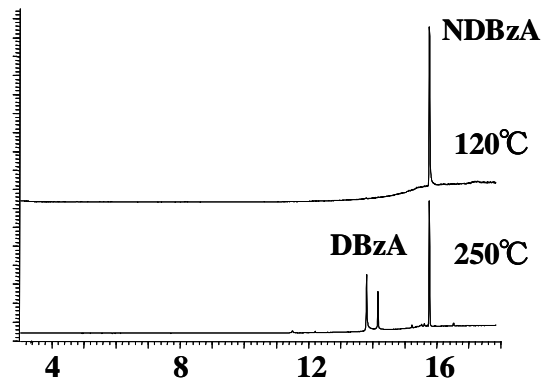

Figure 1. Effect on injection port temperature for SIM chromatogram of NEPhA (1), NMPhA (2) and NDBzA (3).

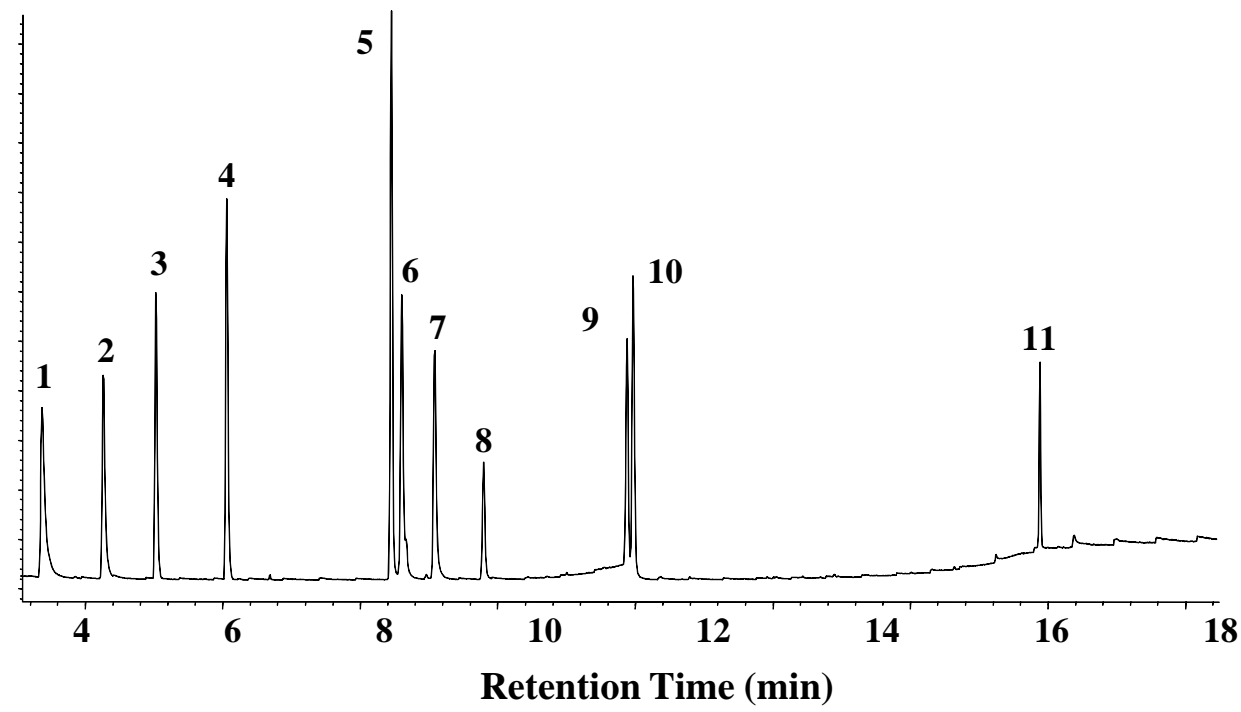

1: NDMA, 2: NDEA, 3: NDiPA (Is), 4: NDPA, 5: NDBA, 6: NPIP, 7: NPYR, 8: NMOR, 9: NEPhA, 10: NMPhA, 11: $\operatorname{NDBzA}(0.2 \mu \mathrm{g} / \mathrm{mL}$ each $)$

Figure 2. GC-MS chromatogram of $N$-nitrosamine standard solution.

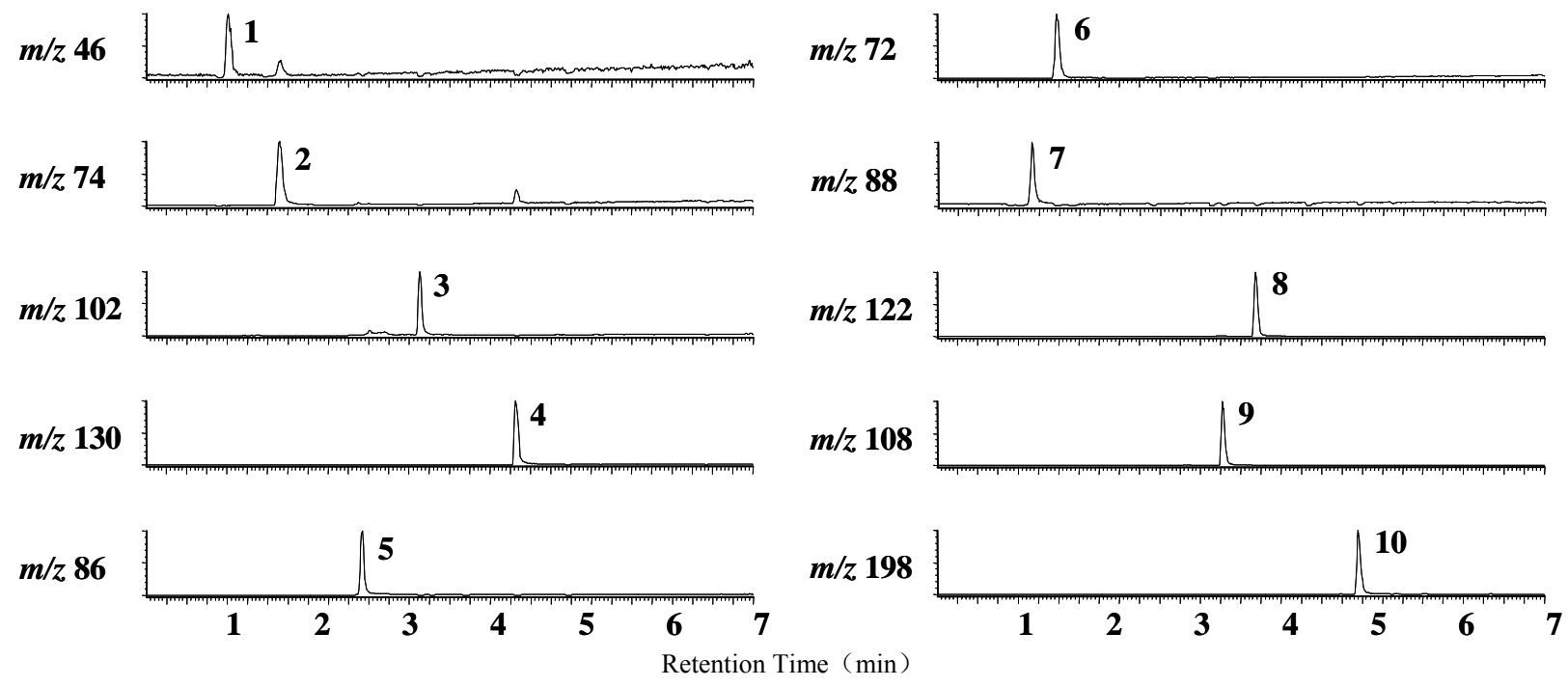

1: DMA, 2: DEA, 3: DPA, 4: DBA, 5: PIP, 6: PYR, 7: MOR, 8: EPhA, 9: MPhA, 10: DBzA (0.02 $\mu \mathrm{g} / \mathrm{mL}$ each)

Figure 3. LC-MS chromatogram of secondary amine standard solution. 


\subsection{Preparation of Test Solutions}

According to EN 12868, migration is conducted with 40 $\mathrm{mL}$ of artificial saliva per $10 \mathrm{~g}$ of teat/soother, but some samples were found to be not fully immersed. To ensure consistent results, in this study, migrations were conducted using $80 \mathrm{~mL}$, twice the volume as in EN 12868 , so that all the samples would be fully immersed in artificial saliva, and then the volume of migration solution was fixed at $100 \mathrm{~mL}$. In addition, in EN 12868, $10 \mathrm{~mL}$ of the $50 \mathrm{~mL}$ of migration solution was used to test the $N$ nitrosatable substances, and the rest was used to test the $\mathrm{N}$-nitrosamines. However, for the latter, this could leave some uncertainty in the determination precision. Therefore, in this study, $75 \mathrm{~mL}$ of the $100 \mathrm{~mL}$ of migration solution was used to prepare the $N$-nitrosamine test solution, $20 \mathrm{~mL}$ for the $N$-nitrosatable substances, and $1 \mathrm{~mL}$ for the secondary amines. Similarly, the volume of $\mathrm{NaOH}$ was doubled and $\mathrm{HCl}$ was added.

\subsection{Additional Recovery Test and Determination Limit}

Recovery tests were carried out in four trials for each concentration and performed by spiking in the migration solution from the silicone rubber and isoprene rubber teats (Teat 1 and Teat 2, respectively) as shown in Tables 3 and 4 . The recovery rates were calculated for each using both the internal standard and absolute calibration methods.

Table 3. Additional recovery rates and determination limits for $N$-nitrosamines.

\begin{tabular}{cccccc}
\hline \multirow{2}{*}{$\begin{array}{c}\text { Nitro } \\
\text { samines }\end{array}$} & \multicolumn{4}{c}{ Recovery rate (\%) } & \multirow{2}{*}{$\begin{array}{c}\text { Determination } \\
\text { limit (mg/kg) }\end{array}$} \\
\cline { 2 - 4 } & \multicolumn{2}{c}{ Absolute calibration } & \multicolumn{2}{c}{ Internal standard } & \\
\cline { 2 - 4 } NDMA & $53 \pm 6$ & $45 \pm 5$ & $63 \pm 1$ & $58 \pm 7$ & 1.5 \\
NDEA & $58 \pm 10$ & $52 \pm 2$ & $79 \pm 6$ & $81 \pm 4$ & 1.5 \\
NDPA & $66 \pm 8$ & $55 \pm 9$ & $93 \pm 2$ & $95 \pm 5$ & 1.5 \\
NDBA & $71 \pm 10$ & $67 \pm 4$ & $93 \pm 5$ & $97 \pm 7$ & 1.5 \\
NPIP & $68 \pm 5$ & $58 \pm 4$ & $93 \pm 2$ & $102 \pm 3$ & 1.5 \\
NPYR & $55 \pm 8$ & $51 \pm 6$ & $80 \pm 4$ & $96 \pm 3$ & 1.5 \\
NMOR & $60 \pm 8$ & $51 \pm 7$ & $80 \pm 4$ & $93 \pm 6$ & 1.5 \\
NEPhA & $74 \pm 13$ & $66 \pm 3$ & $92 \pm 6$ & $99 \pm 5$ & 1.0 \\
NMPhA & $83 \pm 6$ & $69 \pm 4$ & $100 \pm 5$ & $90 \pm 2$ & 1.0 \\
NDBzA & $87 \pm 14$ & $86 \pm 4$ & $103 \pm 9$ & $109 \pm 5$ & 1.0 \\
\hline
\end{tabular}

Teats 1 and 2 are made of silicone rubber and isoprene rubber, respectively; Each value is the mean $\pm \mathrm{SD}$ of four trials.

Table 4. Recovery rates and determination limits of $N$-nitrosatable substances.

\begin{tabular}{|c|c|c|c|c|c|}
\hline \multirow{3}{*}{$\begin{array}{c}\text { Nitro } \\
\text { samines }\end{array}$} & \multicolumn{4}{|c|}{ Recovery rates (\%) } & \multirow{3}{*}{$\begin{array}{l}\text { Determination } \\
\text { limit }(\mathrm{mg} / \mathrm{kg})\end{array}$} \\
\hline & \multicolumn{2}{|c|}{ Absolute calibration } & \multicolumn{2}{|c|}{ Internal standard } & \\
\hline & Teat 1 & Teat 2 & Teat 1 & Teat 2 & \\
\hline NDMA & $61 \pm 10$ & $45 \pm 7$ & $69 \pm 6$ & $59 \pm 7$ & 6.0 \\
\hline NDEA & $52 \pm 13$ & $54 \pm 7$ & $79 \pm 7$ & $80 \pm 6$ & 5.0 \\
\hline NDPA & $67 \pm 17$ & $66 \pm 5$ & $94 \pm 5$ & $99 \pm 5$ & 5.0 \\
\hline NDBA & $78 \pm 11$ & $56 \pm 3$ & $102 \pm 3$ & $85 \pm 1$ & 5.0 \\
\hline NPIP & $76 \pm 12$ & $65 \pm 2$ & $100 \pm 3$ & $98 \pm 6$ & 5.0 \\
\hline NPYR & $68 \pm 12$ & $63 \pm 6$ & $94 \pm 4$ & $92 \pm 5$ & 5.0 \\
\hline NMOR & $79 \pm 12$ & $59 \pm 1$ & $96 \pm 4$ & $90 \pm 4$ & 5.0 \\
\hline NEPhA & $89 \pm 16$ & $63 \pm 6$ & $101 \pm 6$ & $90 \pm 1$ & 4.0 \\
\hline NMPhA & $81 \pm 10$ & $66 \pm 1$ & $100 \pm 3$ & $100 \pm 4$ & 4.0 \\
\hline NDBzA & $79 \pm 15$ & $79 \pm 7$ & $93 \pm 4$ & $94 \pm 3$ & 4.0 \\
\hline
\end{tabular}

Teats 1 and 2 are made from silicone rubber and isoprene rubber, respectively; Each value is the mean \pm SD of four trials. 
When the absolute calibration method was used, the $N$-nitrosamines recovery rates were $70 \%$ or less, except for NMPhA and NDBzA. The recovery rates for Teat 2 were generally lower than those for Teat 1 . On the other hand, when the internal standard method was used, the recovery rates of NDMA were $63 \%$ and $58 \%$ for Teats 1 and 2, respectively. For the others, the rates were 79\% $109 \%$ with standard deviations of $1 \%-9 \%$, which are better than the results from the absolute calibration method. The recovery rates for each of the $N$-nitrosatable substances showed an almost identical tendency to those of the $N$-nitrosamines, ranging from $45 \%$ to $79 \%$ for Teat 2. Moreover, the standard deviation of Teat 1 was large. When the internal standard method was used, the rates for NDMA were low at $69 \%$ and $59 \%$, but for the others, the rates ranged from $79 \%$ to $102 \%$. The standard deviation was small at $1 \%-7 \%$, and the difference between samples was also small. On the basis of the results described above, each $N$-nitrosamine and $N$-nitrosatable substance was determined using the internal standard method.

The determination limit for each $N$-nitrosamine and $N$ nitrosatable substance was set as the amount that could reasonably be determined on the basis of the recovery rate arising from the determination limit of the standard solution and the absolute calibration method (Tables 3 and 4). The determination limits were $1.0-1.5 \mathrm{~g} / \mathrm{kg}$ for the $N$-nitrosamines and $4.0-6.0 \mu \mathrm{g} / \mathrm{kg}$ for the $N$-nitrosatable substances, indicating that for each, determination was possible for up to $1 / 5$ or less and $1 / 15$ or less, respectively, of the EU regulation values.

\section{6. $N$-Nitrosamines, $N$-Nitrosatable Substances, and Secondary Amines in the Rubber Sheet}

An isoprene rubber sheet manufactured with $0.2 \%$ of the vulcanization accelerator that forms NDMA, NDEA, NDBA, NPIP, NMOR, NEPhA, and NDBzA was used for detecting the amount of migration of $N$-nitrosamines, $\mathrm{N}$-nitrosatable substances, and secondary amines (Table 5).

Five kinds of $N$-nitrosamines were detected at 2.1 - 15 $\mu \mathrm{g} / \mathrm{kg}$, but NDBA and NDBzA, which do not tend to dissolve in water or artificial saliva, were not detected. Six kinds of $N$-nitrosatable substances were detected at $30-17,000 \mu \mathrm{g} / \mathrm{kg}$, which is $4.5-4600$ times the amount of $\mathrm{N}$-nitrosamines. All seven kinds of secondary amines were detected at amounts ranging from 0.55 to $98 \mathrm{mg} / \mathrm{kg}$, around $1000-25,000$ times the amount of $N$-nitrosamines.

The amount of $N$-nitrosatable substances indicates the amount of $N$-nitrosamines that are assumed to be formed from secondary amines in the stomach, but the nitrosation reaction percentage is said to vary greatly depending on the compound $[13,17]$. In this study, the percentages also varied greatly from $0.31 \%$ to $94 \%$. The percentage for NEPhA was especially high, with most of the seconddary amines being nitrosated.
Because the reaction percentages varied, the amount of $\mathrm{N}$-nitrosatable substances in the solution was not proportional to the amount of secondary amines. However, except for $\mathrm{NEPhA}$, the amount of secondary amines was around 40 times or more than the amount of $N$-nitrosamines or $N$-nitrosatable substances.

\section{7. $N$-Nitrosamines, $N$-Nitrosatable Substances, and Secondary Amines in the Samples}

Using the three commercially available teats, the migration level of $N$-nitrosamines, $N$-nitrosatable substances, and secondary amines was measured (Tables 6 and 7).

Table 5. Migration amounts of $N$-nitrosamines, $N$-nitrosatable substances, and secondary amines from rubber sheet.

\begin{tabular}{ccccc}
\hline $\begin{array}{c}\text { Nitro } \\
\text { samines }\end{array}$ & $\begin{array}{c}N \text {-nitro } \\
\text { samines } \\
(\mathrm{mg} / \mathrm{kg})\end{array}$ & $\begin{array}{c}N \text {-nitrosatable } \\
\text { substances } \\
(\mathrm{mg} / \mathrm{kg})\end{array}$ & $\begin{array}{c}\text { Secondary } \\
\text { amines } \\
(\mathrm{mg} / \mathrm{kg})\end{array}$ & $\begin{array}{c}\text { Reaction } \\
\text { rate } \\
(\%)\end{array}$ \\
\hline NDMA & 3.9 & 340 & 98 & 0.35 \\
NDEA & 2.1 & 150 & 13 & 1.2 \\
NDBA & ND & 30 & 4.9 & 0.61 \\
NPIP & 12 & 240 & 11 & 2.2 \\
NMOR & 15 & 68 & 22 & 0.31 \\
NEPhA & 3.7 & 17000 & 18 & 94 \\
NDBzA & ND & ND & 0.55 & - \\
\hline
\end{tabular}

Each value is the mean of three trials; $N$-nitrosamines: NDBA: ND $<1.5$, NDBzA: ND $<1.0 ; N$-nitrosatable substances: ND $<4.0$; Other nitrosamines were all ND; Reaction Rate $=N$-nitrosatable substances/secondary amines $\times$ 100 .

Table 6. Amount of migration $(\mu \mathrm{g} / \mathrm{kg})$ of $N$-nitrosamines and $\mathrm{N}$-nitrosatable substances from teats.

\begin{tabular}{|c|c|c|c|c|c|c|}
\hline \multicolumn{2}{|c|}{ Sample } & \multirow{2}{*}{$\begin{array}{l}\text { Material } \\
\text { Silicone }\end{array}$} & \multirow{2}{*}{$\frac{\text { NDMA }}{\text { ND }}$} & \multirow{2}{*}{$\frac{\text { NDEA }}{\text { ND }}$} & \multirow{2}{*}{$\frac{\text { NDBA }}{\text { ND }}$} & \multirow{2}{*}{$\frac{\mathrm{NDBzA}}{\mathrm{ND}}$} \\
\hline \multirow{3}{*}{$\begin{array}{l}N \text {-nitro } \\
\text { samines }\end{array}$} & Teat 1 & & & & & \\
\hline & Teat 2 & IR & ND & ND & ND & ND \\
\hline & Teat 3 & NR & ND & ND & ND & 1.8 \\
\hline \multirow{3}{*}{$\begin{array}{c}N \text {-nitro } \\
\text { satable } \\
\text { substances }\end{array}$} & Teat 1 & Silicone & ND & ND & ND & ND \\
\hline & Teat 2 & IR & ND & ND & ND & ND \\
\hline & Teat 3 & NR & 8.2 & 55 & 9.2 & 5.9 \\
\hline
\end{tabular}

IR: isoprene rubber, NR: natural rubber; Each value is the mean of three trials.

Table 7. Amount of migration $(\mathrm{mg} / \mathrm{kg})$ of secondary amines from teats.

\begin{tabular}{cccc}
\hline Sample & Material & DEA & DBzA \\
\hline Teat 1 & Silicone & ND & ND \\
Teat 2 & IR & ND & 0.41 \\
Teat 3 & NR & 0.19 & 0.34 \\
\hline
\end{tabular}

Each value is the mean of three trials. 
Of the $N$-nitrosamines, $1.8 \mu \mathrm{g} / \mathrm{kg}$ of NDBzA was detected from Teat 3 . Four of the $N$-nitrosatable substances, NDMA, NDEA, NDBA, and NDBzA, were also detected from Teat 3 (natural rubber) at amounts ranging from 5.9 $55 \mu \mathrm{g} / \mathrm{kg}$, with an especially large amount of NDEA, 55 $\mu \mathrm{g} / \mathrm{kg}$. Of the secondary amines, DEA and DBzA were detected from Teat 3 at $0.19 \mathrm{mg} / \mathrm{kg}$ and $0.34 \mathrm{mg} / \mathrm{kg}$, respectively. In addition, $0.41 \mathrm{mg} / \mathrm{kg}$ of DBzA was detected from Teat 2, from which no $\mathrm{N}$-nitrosamines or $\mathrm{N}$ nitrosatable substances were detected. No secondary amines were detected from the silicone-rubber-made Teat 1 .

\subsection{Effects of the Boiling Process}

EN 12868 specifies that, when the test solution is prepared, a sample must be boiled for $10 \mathrm{~min}$ in the minimum amount of water in which it can be immersed. According to EN 1400, this boiling process is intended to check the sample's durability under boiling sterilization and remove the surface coating [25]. During this process, it is possible that $N$-nitrosamines and secondary amines migrate into the boiling water. Therefore, in this study, an isoprene rubber sheet and Teat 3 were used. In order to confirm the effects of the boiling process, we also analyzed the migration level when the boiling process was omitted.

When the rubber sheet was boiled, the $N$-nitrosamines NDMA and NDEA decreased. Among the $N$-nitrosatable substances, NMOR and NEPhA decreased. Other than this, the boiling process had no significant effect (Tables 8 and 9). For Teat 3, of the $N$-nitrosamines, more NDBzA migrated into the boiling solution than into the migration solution. This indicates that NDBzA migrates more easily under boiling conditions, and that the amount of migration increases as well. The $N$-nitrosatable substances decreased slightly because of boiling, but the change was minimal. The secondary amines, except for the DBA in the rubber sheet, all decreased greatly, indicating that they migrate easily during the boiling process.

Secondary amines also migrate in great amounts from articles, and if $\mathrm{N}$-nitrosamines are present in the sample or migration solution, secondary amines are also detected in the boiled solution. The procedure for the secondary amines analysis is simple. Therefore, analyzing seconddary amines in the boiled solution is effective in terms of screening and verification of $\mathrm{N}$-nitrosamines in samples or their migration solutions.

\section{Conclusion}

Many countries have set specifications and recommended standards for $\mathrm{N}$-nitrosamines in rubber teats and soothers. Test methods are often established as well, with measurements using GC-NCD or GC-TEA. However, because few testing laboratories own these devices, it is difficult to conduct these tests in Japan. Therefore, in this study, an analysis method using the more widespread GC-MS method was improved. In this method, the determination limit was $1.0-1.5 \mu \mathrm{g} / \mathrm{kg}$ for $N$-nitrosamines and $4-6 \mu \mathrm{g} / \mathrm{kg}$ for $N$-nitrosatable substances, close to the values listed in EN 12868 and ASTM F1313-90. Determination of $N$-nitrosamines and $N$-nitrosatable substances was possible for up to $1 / 5$ or less and $1 / 15$ or less, respectively, of the regulation values set in the EU Direc-

Table 8. Effect of the boiling process on the amount of migration of $N$-nitrosamines and $N$-nitrosatable substances.

\begin{tabular}{|c|c|c|c|c|c|c|}
\hline \multirow{2}{*}{ Sample } & \multirow{2}{*}{$\begin{array}{l}\text { Nitro } \\
\text { samines }\end{array}$} & \multicolumn{3}{|c|}{$\begin{array}{l}N \text {-Nitrosamines } \\
(\mathrm{mg} / \mathrm{kg})\end{array}$} & \multicolumn{2}{|c|}{$\begin{array}{c}N \text {-Nitrosatable } \\
\text { substances }(\mathrm{mg} / \mathrm{kg})\end{array}$} \\
\hline & & $\begin{array}{l}\text { Without } \\
\text { Boiling }\end{array}$ & $\begin{array}{l}\text { Migrate } \\
\text { solution }\end{array}$ & $\begin{array}{c}\text { Boiled } \\
\text { solution }\end{array}$ & $\begin{array}{l}\text { Without } \\
\text { Boiling }\end{array}$ & $\begin{array}{l}\text { Migrate } \\
\text { solution }\end{array}$ \\
\hline \multirow{7}{*}{$\begin{array}{l}\text { Isoprene } \\
\text { rubber } \\
\text { sheet }\end{array}$} & NDMA & 8.3 & 3.9 & 1.8 & 370 & 340 \\
\hline & NDEA & 3.3 & 2.1 & ND & 150 & 150 \\
\hline & NDBA & ND & ND & ND & 31 & 30 \\
\hline & NPIP & 11 & 12 & 5.9 & 220 & 240 \\
\hline & NMOR & 14 & 15 & 8.6 & 120 & 68 \\
\hline & NEPhA & 3.2 & 3.7 & 3.5 & 43000 & 17000 \\
\hline & NDBzA & ND & ND & ND & ND & ND \\
\hline \multirow[t]{4}{*}{ Teat 3} & NDMA & ND & ND & ND & 9.6 & 8.2 \\
\hline & NDEA & ND & ND & ND & 62 & 55 \\
\hline & NDBA & ND & ND & $\mathrm{ND}$ & 12 & 9.2 \\
\hline & NDBzA & 1.3 & 1.8 & 4.0 & 5.5 & 5.9 \\
\hline
\end{tabular}

Each value is the mean of three trials; $N$-nitrosamines: NDBzA: ND $<1.0$, others: $\mathrm{ND}<1.5$; $N$-nitrosatable substances: $\mathrm{ND}<4.0$; Other nitrosamines were not detected.

Table 9. Effects of the boiling process on the amount of migration of secondary amines.

\begin{tabular}{ccccc}
\hline \multirow{2}{*}{ Sample } & Amines & \multicolumn{3}{c}{ Migration level (mg/kg) } \\
\cline { 3 - 5 } & & Without boiling & With boiling & Boiled solution \\
\hline \multirow{4}{*}{$\begin{array}{c}\text { Isoprene } \\
\text { rubber }\end{array}$} & DMA & 150 & 98 & 82 \\
sheet & DEA & 23 & 13 & 11 \\
& MOR & 4.6 & 4.9 & 1.2 \\
& EPhA & 46 & 11 & 13 \\
& DBzA & 0.81 & 22 & 26 \\
Teat 3 & DMA & 0.55 & 0.55 & 0.75 \\
& DEA & 2.0 & ND & 1.2 \\
& DBA & 0.11 & 0.19 & 0.47 \\
& DBzA & 1.1 & 0.34 & 0.12 \\
\hline
\end{tabular}

Each value is the mean of three trials; $\mathrm{EPhA}$ and $\mathrm{MPhA}$ : ND $<0.2$, others: $\mathrm{ND}<0.1$; Other amines were not detected. 
tive 93/11/EEC. This method had no application problems with respect to selectivity of the detector. Additional recovery rates ranged from $58 \%$ to $109 \%$ for $N$-nitrosamines and $59 \%$ to $102 \%$ for $N$-nitrosatable substances, which are considerably high. Furthermore, screening and verification can be achieved by using LC-MS to measure secondary amines in the boiled solution.

\section{REFERENCES}

[1] International Agency of Research Cancer, "IARC Monographs on the Evaluation of Carcinogenic Risks to $\mathrm{Hu}-$ mans," Some N-Nitrosamines Compounds, 1998.

[2] K. Wakabayashi, "Co-Mutagenic Effect of Norharman with $N$-Nitrosamine Derivatives," Mutation Research, Vol. 80, No. 1, 1981, pp. 1-7. doi:10.1016/0027-5107(81)90172-X

[3] B. L. Pool, et al., "Detection of Mutations in Bacteria and of DNA Damage and Amplified DNA Sequences in Mammalian Cells as a Systematic Test Strategy for Elucidating Biological Activities of Chemical Carcinogens," Food Chemical Toxicology, Vol. 24, No. 6-7, 1986, pp. 685-691. doi:10.1016/0278-6915(86)90158-4

[4] B. G. Boyes, et al., "Evaluation of Genotoxicity of $N$-Nitrosodibenzylamine in Chinese Hamster V79 Cells and Salmonella," Mutation Research, Vol. 241, No. 4, 1990, pp. 379-385. doi:10.1016/0165-1218(90)90068-D

[5] J. Jiao, et al., "Analysis of Tissue-Specific lacZ Mutations Induced by $N$-Nitrosodibenzylamine in Transgenic Mice," Carcinogenesis, Vol. 18, No. 11, 1997, pp. 22392245. doi:10.1093/carcin/18.11.2239

[6] The Commission of the European Communities, "Commission Directive 93/11/EEC Concerning the Release of the $N$-Nitrosamines and $N$-Nitrosatable Substances from Elastomer or Rubber Teats and Soothers," 1993.

[7] ASTM International, "ASTM F1313-90 Standard Specification for Volatile $N$-Nitrosamine Levels in Rubber Nipples on Pacifiers," 2005.

[8] European Committee for Standardization, "EN 12868 Child Use and Care Articles-Methods for Determining the Release of $N$-Nitrosamines and $N$-Nitrosatable Substances from Elastomer or Rubber Teats and Soothers," 1999.

[9] D. C. Havery, et al., "Estimation of Volatile N-Nitrosamines in Rubber Nipples for Babies' Bottles," Food Chemical Toxicology, Vol. 20, No. 6, 1982, pp. 939-944. doi:10.1016/S0015-6264(82)80232-0

[10] M. Takeuchi, et al., "Determination of Volatile N-Nitrosamines in Rubber Nipples by Gas Chromatography Using Thermal Energy Analyzer," Analytical Sciences, Vol. 2, No. 6, 1986, pp. 577-580. doi:10.2116/analsci.2.577

[11] N. P. Sen, et al., "Improved Method for Determination of Volatile Nitrosamines in Baby Bottle Rubber Nipples and Pacifiers," Journal-Association of Official Analytical Chemists, Vol. 70, No. 3, 1987, pp. 434-438.

[12] K. Mizuishi, et al., "N-Nitrosamine Content in Rubber Nipples and Pacifiers, 1988-2007," Annual Report of Tokyo Metropolitan Institute of Public Health, Vol. 34, 1983, pp. 146-149.

[13] K. Mizuishi, et al., "Migration of Secondary Amines from Rubber Nipples and Pacifiers, and Formation of Nitrosamines," Annual Report of Tokyo Metropolitan Institute of Public Health, Vol. 35, 1984, pp. 127-132.

[14] K. Mizuishi, et al., "Hygienic Chemical Survey on Rubber Nursing Products Migrating and Material Test for Nipples and Pacifiers," Annual Report of Tokyo Metropolitan Institute of Public Health, Vol. 37, 1986, pp. 145148.

[15] K. Mizuishi, et al., "Hygienic Chemical Survey on Rubber Products Content of $N$-Nitrosamines in Nipples and Pacifiers," Annual Report of Tokyo Metropolitan Institute of Public Health, Vol. 39, 1988, pp. 97-100.

[16] M. Kuni, et al., "On N-Nitrosamines Migrating from Toys and Rubber Apparatuses," Food Sanitation Research, Vol. 36, No. 7, 1986, pp. 39-49.

[17] T. Tatsuno, et al., "Hygienic Studies on Rubber Nipples (I). Secondary Amines in Commercial Rubber Nipples and Formation of Nitrosamines," Bulletin of National Institute of Hygienic Sciences, Vol. 100, 1982, pp. 62-71.

[18] H. Ishiwata, et al., "Nitrosamines in Rubber Nipples," Bulletin of National Institute of Hygienic Sciences, Vol. 99, 1981, pp. 135-137.

[19] K. Bouma, et al., "Migration of $N$-Nitrosamines, $N$-Nitrosatable Substances and 2-Mercaptobenzthiazol from Baby Bottle Teats and Soothers: A Dutch Retail Survey," Food Additives and Contaminants, Vol. 20, No. 9, 2003, pp. 853-858. doi:10.1080/0265203031000156105

[20] J. E. Grebel et al., "Solid-Phase Microextraction of N-Nitrosamines," Journal of Chromatography A, Vol. 1117, No. 1, 2006, pp. 11-18. doi:10.1016/j.chroma.2006.03.044

[21] B. J. Sanchez, et al., "Comparison of the Sensitivities of Seven $N$-Nitrosamines in Prescreened Waters Using an Automated Preconcentration System and Gas Chromatography with Different Detectors," Journal of Chromatography A, Vol. 1154, No. 1-2, 2007, pp. 66-73.

[22] J. H. Sung, et al., "Liquid Chromatography-Tandem Mass Spectrometry Determination of N-Nitrosamines Released from Rubber or Elastomer Teats and Soothers," Food Additives and Contaminants, Vol. 27, No. 12, 2010, pp. 1745-1754. doi:10.1080/19440049.2010.508184

[23] D. Feng, et al., "Determination of Volatile Nitrosamines in Latex Products by HS-SPME-GC-MS," Chromatographia, Vol. 74, No. 11-12, 2011, pp. 817-825. doi:10.1007/s10337-011-2148-6

[24] D. Feng, et al., "Evaluation of Simulant Migration of Volatile Nitrosamines from Latex Gloves and Balloons by HS-SPME-GC-MS," Journal of Chromatographic Science, Vol. 50, No. 8, 2012, pp. 733-738. doi:10.1093/chromsci/bms057

[25] European Committee for Standardization, "EN 1400 Child Use and Care Articles-Soothers for Babies and Young Children-Chemical Requirements and Tests," 2002. 